\title{
タンパク質中のリガンド結合部位を探索するための手法の開発及び評価
}

\author{
小田彰史
}

\section{Development and Validation of Programs for Ligand-binding-pocket Search}

\author{
Akifumi ODA \\ Faculty of Pharmaceutical Sciences, Tohoku Pharmaceutical University, 4-4-1 Komatsushima, \\ Aoba-ku, Sendai 981-8558, Japan
}

(Received May 27, 2011)

\begin{abstract}
Searching for the ligand-binding pockets of proteins plays an important role in structure-based drug design (SBDD), which is based on knowledge of the three-dimensional structures of target proteins. In SBDD, small molecules that can interact with the target protein are designed. SBDD methods require the identification of ligand-binding pockets, in which ligand molecules interact with protein atoms. The computer programs for the detection of ligand-binding pockets are categorized into two types: one is programs using only geometric properties; and the other is programs using the physicochemical properties of proteins as well as geometry. This paper describes the development and evaluation of a program for ligand-binding pocket search. The program HBOP (Hydropho Bicity On a Protein) searches for ligandbinding pockets using hydrophobic potentials derived from experimentally determined functions. This is based on the fact that hydrophobicity plays a significant role in protein-ligand binding. The results of evaluation indicate that programs using physicochemical properties can discover actual ligand-binding pockets more efficiently than those using only geometric properties.
\end{abstract}

Key words_ — ligand-binding pocket; hydrophobicity; structure-based drug design; docking

\section{1. はじめに}

コンピュータを用いて自然現象の再現や予測を行 う試みの歴史は，コンピュータの歴史そのものとほ ぼ同じ長さを持つ。例えばコンピュータ黎明期にお ける有名な汎用電子計算機 ENIAC は，当初砲弾の 弾道計算を目的として開発が始められたが，これは 紛れもなく物理現象の再現・予測に関する問題であ る. 数学のいくつかの分野は自然科学と関連して発 達してきたため, コンピュータが自然現象の理解に 用いられるのは当然とも言えるが，生命現象に関し てもコンピュータを利用した研究が多くなされてい る。その主な例としては，生体分子の性質や挙動を 物理法則に基づいて計算する計算化学手法や，生物 学的デー夕を情報学的に処理するバイオインフォマ ティクス技術，化学データを取り扱うケモインフォ

東北薬科大学薬学部（干981-8558 仙台市青葉区小松島 4-4-1)

e-mail: oda@tohoku-pharm.ac.jp

本総説は，平成 22 年度日本薬学会東北支部奨励賞（基 礎薬学部門）の受賞を記念して記述したものである.
マティクス技術などがある。このようなコンピュー 夕を利用した生命科学研究のうち, 創薬と密接に関 連した分野の 1 つとしてタンパク質ーリガンド複合 体構造の予測がある.コンピュータによるタンパク 質ーリガンド複合体構造の予測はドッキングと呼ば れ，生体分子の立体構造に基づいた創薬（Structrebased drug design, SBDD）において重要な役割を 果たしている. ${ }^{1)}$ 基質や阻害剤などは生体内で機能 する際，生体高分子によって認識され，複合体を形 成する.この分子認識に際しては水素結合やイオン 間相互作用のような分子間相互作用，さらには疎水 性効果等が働く、コンピュータによるドッキングで はこれらの相互作用等を推定することでタンパク質 ーリガンド間の結合様式を予測し，複合体構造を構 築する。このとき，まずタンパク質とリガンドが相 互作用する場としてリガンド結合部位を同定する必 要がある. 同定されたリガンド結合部位の環境を解 析することで, タンパク質ーリガンド複合体構造予 測がなされる，すなわち，リガンド結合部位の同定 がなされた後にドッキングソフトウェアによってリ 
ガンド分子をタンパク質に結合させることで，タン パク質ーリガンド間の複合体形成について詳細に検 討することができる。このようにリガンド結合部位 の探索はSBDD を行うための第一歩となる操作で あり，SBDD 全体において重要な役割を果たして いる。本稿ではタンパク質中のリガンド結合部位を 同定するための手法の開発・評価について，筆者ら の研究を中心に紹介する.

2.アミノ酸残基の疎水性を指標としたリガンド 結合部位探索手法の開発

リガンド結合部位探索プログラムについては，こ れまでいくつか開発されているが, 2,3) それらのアル ゴリズムは主に 2 種類に分類できる. 1 つはタンパ ク質の立体構造に基づいて幾何学的あるいは物理化 学的にリガンド結合部位を探索する方法で，SBDD ではこちらが主に使用される。もう 1 つはタンパク 質のアミノ酸配列から配列比較などのバイオインフ オマティクス手法を用いて探索する方法で，こちら はタンパク質の機能同定などで使用されることが多 い.タンパク質の立体構造に基づいたリガンド結合 部位探索プログラムもさらに 2 種類に分類できる. 1 つは純粋にタンパク質の形状のみに注目して幾何 学的にリガンド結合部位を探索するプログラムであ る.このタイプのアルゴリズムでは，複数発見され たリガンド結合部位候補のうち最も大きい候補，あ るいは最も深い候補を，真のリガンド結合部位であ る可能性が最も高いと判定することが多い。これは 空洞内部に収まったプローブ球の数が最も多い候補 や，タンパク質の溶媒接触可能表面を算出した後で 凹凸をならした平均平面を求め，そこからの深さが 最も深いくぼみを真のリガンド結合部位であると評 価する方法である。も 1 つはタンパク質の物理化 学的性質を考慮して「リガンド結合部位らしさ」を 評価するプログラムで，こちらは単に大きいという だけではなく，リガンド分子が結合し易いかどうか についても推測する．前者に属するプログラムとし ては alpha-shape アルゴリズムに基づく CAST, ${ }^{4)}$ プローブ球が収まりかつ十分に埋もれているかどう かを判断する PASS, ${ }^{5)}$ タンパク質の cleft を探索す る SURFNET, 6) グリッドを発生させてリガンド結 合部位を探索する $\mathrm{SiteID}^{7)}$ などがある，後者に属す るプログラムとしては有機溶媒プローブとの相互作 用を計算する computational mapping 法によるポケ
ット探索, ${ }^{8)}$ メチルプローブに対する相互作用を計 算する Q-SiteFinder, ${ }^{9)}$ そしてわれわれの研究チー ムで開発した HBOP ${ }^{10,11)}$ がある.

HBOP は経験的な疎水性ポテンシャル12) 用い てリガンド結合部位を同定する。これは，タンパク 質ーリガンド結合において疎水性が重要な役割を果 たすという知見 ${ }^{13)}$ に基づいている.このプログラム の動作について Fig. 1 に示す。まずタンパク質の 周囲に $10 \AA$ の厚みで $1 \AA$ 間隔のグリッドを発生さ せ，その各グリッド点における疎水性ポテンシャル を計算する。この疎水性ポテンシャルについては, Israelachvili らによる経験式

$$
\begin{aligned}
& \Delta G_{\mathrm{H}}=-2.0 R_{i j} \exp \left(-D_{i j} / 10\right) \\
& R_{i j}=R_{i} R_{j} /\left(R_{i}+R_{j}\right) \\
& D_{i j}=d_{i j}-\left(R_{i}+R_{j}\right)
\end{aligned}
$$

を使用して求める。 ここで $R_{i}$ 及び $R_{j}$ はそれぞれ夕 ンパク質及びプローブの炭素原子の半径である。こ こでプローブとしては $s p^{3}$ 炭素を用い，半径 $R_{j}=$ $1.52 \AA ̊$ とした。 また $d_{i j}$ はタンパク質中の原子とプ ローブの原子との間の距離である。これは疎水性表 面間に㗢く引力的な自由エネルギー変化を実験によ って測定し，その值から経験的に得られた数式であ る.この式は疎水性ポテンシャルが指数関数的に減 衰することを示しており，タンパク質による分子認 識等を考える際に van der Waals 力と比較してより 長距離相互作用的に働くことがわかる．HBOPで は，疎水性ポテンシャルの計算にはタンパク質の疎 水性アミノ酸残基（Gly，Ala，Val，Leu，Ile，Met,
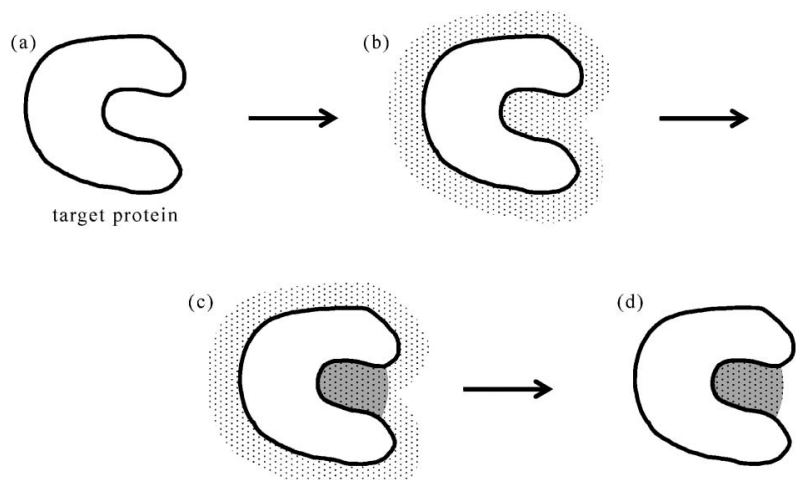

Fig. 1. Ligand Binding Pocket Search Procedure of HBOP (a) Target protein. (b) Grid points are generated around the target protein. (c) Hydrophobic potential on the grid points are calculated. Highly hydrophobic area is shown by gray. (d) The grid points whose hydrophobic level is lower than HB6 are rejected. The remained grid points are predicted ligand binding pockets. 
Trp, Phe, Pro）のみに注目し，これら疎水性残基の アミド炭素を除く炭素原子のみを使用した．各グリ ッド点に対して得られた疎水性ポテンシャルを 20 段階に分割し，疎水性ポテンシャルが上位 $30 \%$ 以 内のグリッド点をリガンド結合部位として推定す る. 具体的には，得られた疎水性ポテンシャルのう ち最大值を $\Delta G_{\mathrm{H}}^{\max }$ ，最小值を $\Delta G_{\mathrm{H}}^{\min }$ とすると，疎 水性ポテンシャルの值を $0.05 \times\left(\Delta G_{\mathrm{H}}^{\max }-\Delta G_{\mathrm{H}}^{\min }\right)$ 毎に 20 段階に分類する。 その分類に応じてグリッ ド点をクラス分けし，疎水性の高い方から HB1， HB2，……する。 ここで HB6 までのグリッド点 をリガンド結合部位とする．経験的な疎水性ポテン シャルやグリッド点を使用しているためこのプログ ラムは計算機資源の面においても非常に優れてお り，それほどパワーのないコンピュータを使用して も十分高速に実行が可能である.

また，HBOP で発生させたグリッド点をクラス タリングし，他のプログラムと同様の体積を持った 「結合サイト」を検出するプログラム HBSITE も開 発している。これは隣接するグリッド同士をグルー プ化し，10 点 $\left(10 \AA^{3}\right)$ 以上集まった場合そのグルー プを「結合サイト」と定義するプログラムである. HBOP ではグリッド点でリガンド結合部位を表現 するが，HBSITEによってある程度の体積を持つ たサイトを同定することができ，またリガンドが収 まらないほど狭い隙間を排除して計算の効率化を図 ることもできる，HBSITEで同定された結合サイ トは「リガンド結合部位らしさ」に応じて順位付け されるが，サイトの体積（サイトに含まれるグリッ ド点の数）が大きいほどリガンド結合部位らしいと 判断する HBSITE（size）基準と，サイトに含まれ るグリッド点の疎水性が高いほど（サイト中に疎水 性の高いグリッドが多く含まれているほど）リガン ド結合部位らしいと判断する HBSITE（HB）基準 の 2 通りの順位付けを行っている.

\section{3. リガンド結合部位探索手法の評価}

筆者らは HBOP 及び HBSITE の開発と並行し て，その能力の評価についても行った．テストに際 しては立体構造既知の 458 個のタンパク質ーリガン ド複合体をテスト系として使用した。これらは FlexX-200 テストセット, ${ }^{14,15)}$ Wang のテストセッ ト, ${ }^{16)}$ Glide のテストセット, ${ }^{17)}$ Kontoyianni のテス トセット, ${ }^{18)}$ Perola のテストセット19,20)のうちで,
重複を除き，リガンドがタンパク質と共有結合して いない系である，HBOP 及び HBSITE に加え，比 較のためにPASS, SiteID, Q-SiteFinder による試験 も行った．計算の設定としてはデフォルトの值を使 用した。リガンド結合部位が正しく認識されている かどうかの判断基準として，PASS では結晶構造の リガンド分子から $6.5 \AA$ 以内に site point を置くこ とができたかどうかを調べた。また，SiteIDでは リガンド分子から $3.0 \AA$ 以内に, Q-SiteFinder では $1.0 \AA ̊$ 以内に， HBOP でも $1.0 \AA$ 以内清ガンド結 合部位を構成するグリッド点が存在するかどうかを 判断基準に使用した.PASS の判定基準はリガンド の位置を基準とした場合によく使用されるリガンド 結合部位の定義15)に準じており，SiteID は分子モ デリングプログラムSYBYL におけるデフォルトの 定義を参照した。また，HBOP はグリッド間隔から 考えて最も厳しい判定基準を採用した。 Q-SiteFinder ではグリッド解像度は $0.9 \AA$ であるが，HBOP に合わせてより寛大な值を使用した，HBSITE で 作成したサイトについては，サイトの大きさ（サイ ト中に含まれるグリッド点の数）の順に順位付けし た HBSITE（size）と，サイトの疎水性（疎水性ス コアが最上位だったグリッド点の数）の順に順位付 けした HBSITE（HB）の両方について比較を行っ た.

また，より実際の創薬に近いテストとして，リガ ンドを結合していない構造を使用したテストも行つ た．タンパク質の立体構造はリガンドの結合に伴っ て変化することが知られているが，実際の創薬では リガンドの結合する前の構造しか使用できない場合 もある.このテストは，そのような場合にも正しく リガンド結合部位を認識できるかどうかを評価する ために行った。使用した系は論文 ${ }^{9}$ に記載されてい る 35 種類のタンパク質である。これらのテストセ ットは論文 ${ }^{9)}$ において Q-SiteFinder の能力を評価す るために用いられた系である。 また，プログラムと しては HBSITE (HB) とQ-SiteFinderを使用した。 まずリガンドを結合していないタンパク質に対して リガンド結合部位探索を行い，発見されたリガンド 結合部位が実在のタンパク質ーリガンド複合体にお いて真のリガンド結合部位となっているかどうか調 ベることで評価を行った，すなわち，もともと複合 体として解析されたタンパク質立体構造を使うこと 
なく，リガンド非結合状態のタンパク質の構造を用 いて正しくリガンド結合部位を探索できるかどうか をテストした。このとき正しく調査できたかどうか の評価基準となる複合体構造についても論文 ${ }^{9)}$ に記 されているものを使用した。評価の際にはリガンド の結合していないタンパク質とリガンドの結合した タンパク質の主鎖を重ね合わせ，リガンド非結合状 態に対して同定されたリガンド結合部位が，リガン ド結合状態においてリガンドの存在する位置に対応 するかどうかで評価した。

Table 1 に 458 個の系でのリガンド結合部位探索 の結果を示した。ここでは，リガンド結合部位候補 の順位については考慮せず，各プログラムが発見し たリガンド結合部位候補の中に実際のリガンド結合 部位があるかどうかだけを検討した。ここに示した ように, HBOP で真のリガンド結合部位を発見で きなかった系は 12 個と最も少なかった．HBOP の 結果をクラスタリングして結合サイトを同定する HBSITE でもリガンド結合部位同定に失敗した系 は 25 個であり，これはPASS や SiteID と比較して 優れている．また，1つの系あたりに発見されたリ ガンド結合部位候補の数は HBSITE が最も少なか つた。予測されたリガンド結合部位候補の数が多い ということは偽陽性の候補が多く含まれているとい うことを意味しているため，予測された候補数の少 ない HBSITE は最も効率的に真のリガンド結合部 位を探索することができると考えられる．また，QSiteFinder（24 個の系で失敗している）は HBSITE とほぼ同程度の結果が得られている。しかし QSiteFinder はすべての系に対して 10 個のリガンド 結合部位候補を出力するため, 候補数はすべての手 法の中で最大となっている。 したがって，成功数で は HBSITE とほぼ同等ではあるものの，効率の面 では HBSITE に劣っていることになる。一方, SiteID では 71 個の系で真のリガンド結合部位を探
索することができず，そのうち9つの系ではそもそ も予測されたリガンド結合部位候補が 1 つもない （見当外れな候補さえみつからない）という結果で あった。 PASS はリガンド結合部位探索能力として は HBOP と SiteID の中間に位置していたが，1つ の系あたりに予測されたリガンド結合部位候補数が 多く, 効率の点で劣っていることが示唆される.

ここで，HBOP で真のリガンド結合部位を発見 できなかつた系についてみてみよう。 Table 1 に示 したのは HB6 までに真のリガンド結合部位があつ た系であるが，これを HB10までに拡張すると失 敗した系はわずかに 2 つなる。HB7 から HB10 までに真のリガンド結合部位のある系はすべて 2 本 鎖以上を持つタンパク質であり，これらの鎖間の疎 水性領域に高いスコアをつけてしまった結果，真の リガンド結合部位の疎水性スコアが相対的に低下し ているものと考えられる。このような複数鎖からな るタンパク質に対しては，1 本鎖のみを考えたり， HB10 付近まで調査したりすることで，見落としは なくなるものと考えられる。一方，HB10 までみて も真のリガンド結合部位を探索できなかったのは PDB ID で $1 \mathrm{CDG}, 5 \mathrm{CNA}$ の 2 づあった（1CDG はHB13 に，5CNA は HB14 に真のリガンド結合 部位が存在していた)。1CDG はシクロデキストリ ングリコシルトランスフェラーゼとマルトースの複 合体，5CNA はコンカナバリン A と $\alpha$-メチル-D-マ ンノピラノシドの複合体であり，これはどちらも糖 及びその類縁体がタンパク質表面の浅い部位にドッ キングした構造を持っている。糖のドッキングにつ いては，場合によっては通常のアプローチと異なっ た手法を用いる必要があることが知られてお

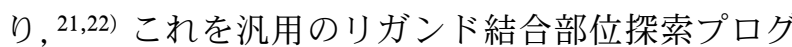
ラムで考慮するのは限界がある。一方で今回テスト に使用した複合体のうち，酸素以外のへテロ原子や 疎水性基を持たない糖誘導体をリガンドとしたもの

Table 1. Results of the Tests for Ligand-binding-pocket Search Using 458 Protein-ligand Complex Structures

\begin{tabular}{|c|c|c|c|c|c|}
\hline & HBOP & HBSITE & PASS & SiteID & Q-SF ${ }^{\mathrm{a}}$ \\
\hline Number of successful test ${ }^{b}$ & 446 & 433 & 420 & 387 & 434 \\
\hline Number of failed test ${ }^{c}$ & 12 & 25 & 38 & 71 & 24 \\
\hline Average number of candidate & - & 4.64 & 9.53 & 8.70 & 10.0 \\
\hline
\end{tabular}

${ }^{a}$ Q-SF: Q-SiteFinder. ${ }^{b}$ Number of the test systems for which actual ligand-binding pockets were successfully detected. ${ }^{c}$ Number of the test systems for which actual ligand-binding pockets were not detected. 
は 20 個あった。これらのリガンドでは糖構造以外 に相互作用点となり得る特性基を持っていないこと を考えると，90\%の複合体（20 個中 18 個）で正し い結合部位を発見できたことは，むしろ上述のよう な限界にもかかわらず HBOP のリガンド結合部位 探索能が糖の結合部位探索においても高いことを意 味している。なお，この 2 つの系はPASS 及び SiteID, Q-SiteFinder でも真のリガンド結合部位が 探索できておらず，通常のリガンドドッキングを視 野に入れたリガンド結合部位探索手法では扱うのが 困難な系ではないかという考察を支持している.

次に，予測されたリガンド結合部位候補を順位付 けし，その第何位の候補が実際のリガンド結合部位 であったかを調べた結果を Fig. 2 に示す。ここに は，第 1 位のリガンド結合部位候補が正解だつた系 の数と，上位 3 位までに実際のリガンド結合部位が 存在していた系の数をそれぞれ図示している。すな わち，最上位の候補がまさに「正解」だった場合と，

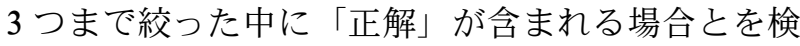
討した。ここに示したように，第1 位のリガンド結 合部位候補が正解だった系の数も上位 3 位までに実 際のリガンド結合部位が存在していた系の数も，疎 水性スコアを基にした HBSITE が最も多かった. ただし，第 1 位のみをみた場合については QSiteFinder も同数であった．第 3 位までみた場合に ついては HBSITE（HB）が Q-SiteFinderをも上回 っている，加えて，上位 3 位までに実際のリガンド 結合部位が存在していた系の数をみると, HBSITE (HB) のみならず HBOP, HBSITE (size) も PASS, SiteID, Q-SiteFinder よりも多かった。これは HBOP によるリガンド結合部位探索が有効に機能している

- top ranked pocket $\square$ top 3 pocket

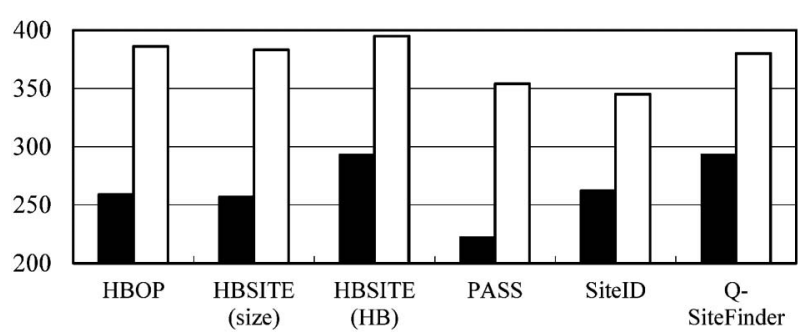

Fig. 2. Number of Tests in Which the Top-ranked Pocket Candidate or One of the Top Three Pocket Candidates Was the Actual Ligand-binding Pocket
ことを示しているが，その中でも $\operatorname{HBSITE（HB）}$ が最も良好な結果を与えたことは，疎水性によって 結合部位候補の順位付けを行うのが有効であること を示唆している。すなわち，HBOP の結果をその まま使用するよりも HBSITE でクラスタリング し，かつ疎水性スコアで順位付けしたほうが効率的 に真のリガンド結合部位を発見できることがわかつ た。また，Q-SiteFinder も PASS やSiteID より良 好な結果を与えており，このことはリガンド結合部 位探索において PASS や SiteID のように単純に夕 ンパク質の形だけを考えるのではなく， HBOP, HBSITE や Q-SiteFinder のようにタンパク質の物 理化学的性質についても考慮した方がよいことを示 唆している.

リガンドの結合していないタンパク質（unbound と表記）に対するリガンド結合部位探索の結果を Table 2 に示す．また，第 1 位のリガンド結合部位 候補の夕をみた場合（Top-ranked pocket），上位 3 位の候補をみた場合（Top three pockets），順位に 関係なく成功数をみた場合（All pockets）のそれぞ れについて記載した。比較のため，評価に使用した リガンドを含んだ複合体（bound と表記）に対す る探索の結果も併記している。いずれも，35 個の 系のうちいくつで真のリガンド結合部位を探索でき たかを示している. 458 個の系に対するテストでは HBSITE (HB) と Q-SiteFinder はほぼ同等の能力 であったが，unboundの系に対しては明らかに HBSITE（HB）のほうが順位付けに成功している. なお，順位付けを無視した all pockets では 458 個 の系で行ったテストとほぼ同等の結果となってお り，これらの問題は順位付けの際に発生している. 比較のために行った bound の系では 458 個の系と 無矛盾な結果となっていることから，これは un-

Table 2. Results of the Tests for Ligand-binding-pocket Search Using Ligand-bound and Unbound Protein Structures

\begin{tabular}{lcc|cc}
\hline \hline Test system & \multicolumn{2}{c|}{ Bound } & \multicolumn{2}{c}{ Unbound } \\
Programs & $\begin{array}{c}\text { HBSITE } \\
\text { (HB) }\end{array}$ & Q-SF $^{\mathrm{a}}$ & $\begin{array}{l}\text { HBSITE } \\
(\text { HB })\end{array}$ & Q-SF $^{\mathrm{a}}$ \\
\hline Top-ranked pocket & 30 & 27 & 30 & 21 \\
Top three pockets & 34 & 32 & 35 & 29 \\
All pockets & 34 & 34 & 35 & 34 \\
\hline
\end{tabular}

a Q-SF: Q-SiteFinder. 
bound な状態に対して HBSITE（HB）が有効にリ ガンド結合部位候補を順位付けできることを示して おり, HBSITE (HB) が多少の構造変化に対して ロバストであることが示唆される。これは QSiteFinder では 6-12 型の van der Waals 相互作用を 使用しているのに対して，HBOP 及び HBSITE で 使用される疎水性ポテンシャルが長距離相互作用関 数であるためではないかと考えられる。すなわち， 構造上のわずかな差異で評価関数が大きく值を変え ることがないことが，このロバストさにつながって いるのではないだろうか。 したがって，高解像度で 信頼できるタンパク質ーリガンド複合体立体構造が 得られるような状況では Q-SiteFinder も有効に機 能するが，複合体構造が得られておらず，完全に新 規にリガンド結合部位予測を行うような場面では HBSITE（HB）のほうが適切にリガンド結合部位 を同定し，順位付けできるのではないかと期待でき る.

\section{4. おわりに}

本研究では，疎水性を指標にしてタンパク質のリ ガンド結合部位を探索するプログラムの開発を行 い，その能力評価もまた行った。その結果，疎水性 を指標としてリガンド結合部位探索を行う HBOP 及び HBSITE が，幾何学的性質の夕を基に探索す る PASS, SiteID よりも優れた結果を与えることが わかった。また，メチルプローブを使用する QSiteFinder と比較すると, タンパク質ーリガンド複 合体構造が得られていないような系に対しても HBSITE が有効に機能することがわかった。 HBOP は疎水性の相対值を評価基準としているため，二本 以上のペプチド鎖からなるタンパク質については疎 水性の高いペプチドーペプチド（あるいはタンパク 質ータンパク質）界面に評価が偏ってしまい，低分 子化合物のリガンド結合部位が過小評価される傾向 があった。これは HBOP, HBSITE の欠点ではある が，逆にタンパク質ータンパク質ドッキングサイト の同定に応用できる可能性も示している．また，こ のような欠点にかかわらず，複数のペプチド鎖を持 つようなタンパク質に対しても HBOP, HBSITE は 他のプログラムよりも良好な結果を与えている.

本研究では HBOP 及び HBSITE の開発及び評価 を行った.これらのプログラムによって疎水性ポテ ンシャルを割りあてられたグリッド点は，リガンド
結合部位探索だけではなく，ドッキングによるタン パク質ーリガンド複合体構造の推定にも有効に使用 できる可能性がある. ドッキングにおいて重要な相 互作用等のうち，疎水性の効果は水素結合などの指 向性の相互作用と比べて定義が難しいが，HBOP で求められたグリッド点を空間的な制約として使用 することによって疎水性の効果をドッキングに利用 できるのではないかと考えられる，今後，そのよう な発展的な研究が進むことを期待したい。なお， HBOP 及び HBSITE はアカデミックフリーである [入手を希望する場合は, 北里大学薬学部・山乙教 之助教（yamaotsun@pharm.kitasato-u.ac.jp）まで 連絡]。

謝辞本研究の遂行にあたつてご指導, ご鞭撻 を賜りました北里大学薬学部の広野修一教授, 山乙 教之助教, 東北薬科大学の高橋央宜准教授に深く感 謝いたします。

\section{REFERENCES}

1) Kitchen D. B., Decornez H., Furr J. R., Bajorath J., Nat. Rev. Drug Discov., 3, 935949 (2004).

2) Campbell S. J., Gold N. D., Jackson R. M., Westhead D. R., Curr. Opin. Struct. Biol., 13, 389-395 (2003).

3) Sotriffer C., Klebe G., Farmaco, 57, 243-251 (2002).

4) Jie L., Edelsbrunner H., Woodward C., Protein Sci., 7, 1884-1897 (1998).

5) Brady G. P. Jr., Stouten P. F., J. Comput. Aided Mol. Des., 14, 383-401 (2000).

6) Laskowski R. A., Luscombe N. M., Swindells M. B., Thornton J. M., Protein Sci., 5, 24382452 (1996).

7) “SiteID,” Tripos Inc., St. Louis, 2004.

8) Dennis S., Kortvelyesi T., Vajda S., Proc. Natl. Acad. Sci. USA, 99, 4290-4295 (2002).

9) Laurie A. T. R., Jackson R. M., Bioinformatics, 21, 1908-1916 (2005).

10) Yamaotsu N., Oda A., Hirono H., Biol. Pharm. Bull., 31, 1552-1558 (2008).

11) Oda A., Yamaotsu N., Hirono S., J. Comput. Chem., 30, 2728-2737 (2009).

12) Israelachvili J. N., Pashley R. M., Nature, 300, 341-342 (1982). 
13) Ajay A., Murcko M. A., J. Med. Chem., 38, 4953-4967 (1995).

14) Rarey M., Kramer B., Lengauer T., Bioinformatics, 15, 243-250 (1999).

15) Kramer B., Rarey M., Lengauer T., Proteins, 37, 228-241 (1999).

16) Wang R., Lu Y., Wang, S., J. Med. Chem., 46, 2287-2303 (2003).

17) Friesner R. A., Banks J. L., Murphy R. B., Halgren T. A., Klicic J. J., Mainz D. T., Repasky M. P., Knoll E. H., Shelley M., Perry J. K., Shaw D. E., Francis P., Shenkin P. S.,
J. Med. Chem., 47, 1739-1749 (2004) .

18) Kontoyianni M., McClellan L. M., Sokol G. S., J. Med. Chem., 47, 558-565 (2004).

19) Perola E., Charifson P. S., J. Med. Chem., 47, 2499-2510 (2004).

20) Perola E., Walters W. P., Charifson P. S., Proteins, 56, 235-249 (2004).

21) Taroni C., Jones S., Thornton J. M., Protein Eng., 13, 89-98 (2000).

22) Shionyu-Mitsuyama C., Shirai T., Ishida H., Yamane T., Protein Eng., 16, 467-478 (2003). 